\title{
Feeding Rabbits in Traditional System With Improved Forage Legumes in South-Kivu. D. R. Congo
}

\author{
D. M. M. Katunga (Corresponding author) \\ International Center For Tropical Agriculture (CIAT), Bukavu, D. R. Congo \\ Current address: National Institute of Studies and Agriculture Researches (INERA) Mulungu \\ Bukavu, D. R. Congo \\ E-mail: katungamusale@yahoo.fr
}

J. B. Muhigwa

Université Officielle de Bukavu, D. R. Congo

E-mail: jeanmuhigwa@yahoo.fr

\section{J. C. K. Kashala}

Faculté de médecine vétérinaire, Université de Lubumbashi, BP 1825,

Lubumbashi, D R Congo

E-mail: jckkashala@live.fr

\section{Y. Mbuyi}

Faculté de médecine vétérinaire. Université de Lubumbashi BP 1825

Lubumbashi, D R Congo

V. Okombe

Faculté de médecine vétérinaire. Université de Lubumbashi BP 1825

Lubumbashi, D R Congo

K. F. Balemirwe

CIAT Bukavu, Email: fidelkatunga@yahoo.fr 


\title{
II Macrothink
}

Received: August 14, 2014 Accepted: October 26, 2014 Published: November 4, 2014

Doi: 10.5296/jab.v3n1.6549 URL: http://dx.doi.org/10.5296/jab.v3n1.6549

\begin{abstract}
To investigate for an efficient feeding of rabbits in the traditional system essentially with some improved high yield forage legumes. Two animal nutrition trials were conducted from September 2011 to February 2012 in Mugwahi farm in Nyangezi, South-Kivu, D. R. Congo. Five female rabbits replicated three times were fed essentially in traditional system with supplements of improved forage legumes; first with Leucaena diversifolia from the selection of CIAT in Colombia and second with Desmodium intortum. Five others as local controls were fed only on local forages.

The palatability evaluation showed that Calliandra calothyrsus was most appreciated by rabbits; Desmodium intortum and Leucaena diversifolia had a moderate palatability. The weight gain showed that rabbits which received a supplement of Leucaena diversifolia grew better than those fed on local forages.

In term of palatability, the various forages supplied to female rabbits only $C$. calothyrsus performed significantly with a high RIP during the first trial and the improved forages $D$. intortum and $L$. diversifolia had a moderate one during the second trial. Regarding the weight gain of rabbits, the introduced forages; L. diversifolia performed better than the local ones. The cropping of improved legumes constitutes an alternative to avoid long walks to collect fodder which is scarce in villages. These good forages on farm could remain available even in the dry season. Studies to determine the constraints of adoption of forage crops by the farmers will improve forage production.
\end{abstract}

Keywords: Forage legumes, Rabbits, Palatibility, Weight gain 


\section{Introduction}

Farming in the South-Kivu Province of the Democratic Republic of Congo is characterized by an extensive animal-agriculture system (Maass, 2012). The demographic inflation and the subsequent pressure on natural resources shall boost a change of agricultural practices and livestock husbandry while shifting toward semi-intensification or intensified systems (Katunga, 2004). Forage crops to feed rabbits are scarcely applied in the region (Maass, 2012), though they could help breeders to turn toward more appropriate practices, responding to conditions of land scarcity with shortages of pastures within a context of increasing food demand and protein malnutrition. Human food is generally expensive and cannot allow farmers to secure profits when it is used as livestock feed. This paper aims at investigating for an efficient feeding of rabbits in the traditional system essentially with some improved high yield forage legumes with high nutritional values from the selection of the CIAT in Colombia (CIAT, 2008).

\section{Materials and Methods}

\subsection{Location and Characteristics of the Study Site}

All of the animal nutrition trials were conducted at Mugwahi farm in Nyangezi, about $30 \mathrm{~km}$ South of Bukavu (Latitude $2.88^{\circ} \mathrm{S}$, Longitude $27.03^{\circ} \mathrm{E}$ ), the elevation is of ca. $1580 \mathrm{~m}$ asl. The soil is acidic with $\mathrm{pH} 3.9$.

\subsection{Origin of Animals and Animal Husbandry}

A total of 30 females rabbits, six months old were received from Sisters' Monastery of Murhesa during the trial with Desmodium intortum and the same animals of nine months old during the trial with Leucaena diversifolia. They were local breeds mixed at low level with Californian and Flanders giant breeds. Five animals were kept in wooden boxes $1.2 \mathrm{~m} \times 0.6$ $\mathrm{m} \times 0.6 \mathrm{~m}$. Then five rabbits formed a group replicated three times.

\subsection{Feeds and Nutritional Quality}

Overall, two trials were conducted. First the supplement of D. intortum began on September, $27^{\text {th }} 2011$ and finished on December, $20^{\text {th }} 2012$ and the second one with L. diversifolia with the same animals in December, $28^{\text {th }} 2012$ to February, $20^{\text {th }} 2012$.

In the first trial, five female rabbits replicated three times were fed $75 \%$ on local grasses plus $25 \%$ supplement of $D$. intortum and five other female rabbits replicated three times received the local feed only. During the second trial with supplement feeding on L. diversifolia, fifteen female rabbits received $75 \%$ of local feeding plus $25 \%$ supplement of $L$. diversifolia and fifteen others on the local feed only. All rabbits were accustomed for two weeks in the first trial and one week in the second one before the feeding trials started. Animals were fed at 8:0 am and 16:0 pm. Water was unlimitedly supplied throughout the experiments. All animals were fed "ad libitum". Foliages were harvested without any restriction of age and species following the farmer practices. Local feeds were collected from road, path sides and swamp and crop residues in the surroundings according to availability. Improved forage legumes were planted in a nearby field, harvested in the morning. All the forages were supplied to rabbits when slightly wilted. Nutritive values were mostly assessed by Near Infrared Reflectance Spectroscopy (NIRS) at ILRI-Ethiopia. Time of harvesting the forages was about two hours per meal per person and could require seven kilometers walk some days but 
usually three kilometers. The samples for chemical analysis were all collected on young leaves after the trials.

\subsection{Palatibility of Feeds and Development of Animal Weights}

The various feed stuffs were identified and weighed on a hanging scale (KERN \& Sohn $\mathrm{GmbH}$ ) with $5 \mathrm{~g}$ minimum and $10 \mathrm{~kg}$ maximum in order to assess their availability. Thereafter, they were dispatched into similar portions and species to provide every one rabbit per cage with an equal amount of $600 \mathrm{~g}$ of feed from each component. This resulted in variable amounts as well as different compositions of individual feeds day by day (Table 2). Before every meal, feed remains were collected, identified and weighed and the quantity of feed species refusals noted. The feed availability and the composition of grasses were calculated at each meal during the two trials. The Relative Index of Palatability (RIP) formula was FeedXcons $(\%)=($ FeedXoffered $(\mathrm{g})$-FeedXrefused $(\mathrm{g})) /($ FeedToffered $(\mathrm{g}))$-FeedTrefused $(\mathrm{g}))$ FeedXoffered $(\%)=($ FeedXToffered $(\mathrm{g})) /($ FeedToffered $(\mathrm{g}))$.

$\mathrm{RIP}=($ FeedXcons $(\%)) /($ FeedXoffered $(\%))$ where; low palatability $(\mathrm{RIP} \leq 0.8)$; moderated palatability $(\mathrm{RIP}=\leq 0.8-1.2)$ and highly palatability $(\mathrm{RIP}=>1.2)$.

To follow up the development of animal weights, every animal was weighed once a week only for the trial with $L$. diversifolia supplement with the same hanging scale.

\subsection{Data Analysis}

For data analysis, Anova, Tukey test and clusters were run on STATVIEW version 5.0, Past version 2.15, STATISTICA 6 and Genstat for Teaching sofwares.

\section{Results}

\subsection{Nutritive Values of Foliages}

The Table1 presents the chemical analysis of various foliages eaten by the rabbits.

The different foliages represented in Table 1 show good nutritive values. Crude proteins ranged from 15.3-28.7\% which is very good. Values of ADF concentration for Bidens pilosa, Brachiaria ruziziensis, Calliandra calothyrsus, Dichrocephala integrifolia, Erlangea sp., Ipomoea batatas, Trifolium baccarinii were very good as well. The other forages have a very high ADF especially Albizzia gummifera. 
Table 1. Chemical composition of the meal (\%)

\begin{tabular}{|c|c|c|c|c|c|}
\hline Forage species & DM* & $\mathbf{O M}$ & $\mathbf{C P}$ & NDF & ADF \\
\hline Albizzia gummifera & 26.5 & 95.8 & 28.7 & 74.9 & 54.1 \\
\hline Bidens pilosa & 26.8 & 82.4 & n.d* & 48.2 & 26.0 \\
\hline Brachiaria ruziziensis & 30.9 & 84.5 & 15.9 & 64.9 & 30.5 \\
\hline Calliandra calothyrsus & 29.5 & 96.2 & 23.7 & 41.6 & 28.1 \\
\hline Conyza sumatrensis & 28.2 & 83.6 & n.d & 45.0 & 49.2 \\
\hline Crassocephalum monteosum & 24.4 & 85.2 & n.d & 46.2 & 49.3 \\
\hline Crassocephalum vitellinum & 20.4 & 81.8 & 17.1 & 48.1 & 52.9 \\
\hline Desmodium intortum & 23.4 & 92.4 & 22.2 & 64.1 & 47.3 \\
\hline Dichrocephala integrifolia & 20.8 & 86.5 & 27.7 & 46.9 & 28.0 \\
\hline Digitaria vestita & 29.5 & 88.8 & n.d & 78.4 & 46.2 \\
\hline Drimaria cordata & 23.5 & 89.8 & 20.9 & 59.8 & 36.1 \\
\hline Erlangea sp. & 30.1 & 84.9 & n.d & 51.0 & 27.4 \\
\hline Galinsoga parviflora & 19.5 & 84.3 & 24.1 & 40.5 & 39.0 \\
\hline Ipomoea batatas & 23.4 & 86.2 & 23.7 & 26.6 & 20.4 \\
\hline Leucaena diversifolia & 32.1 & 94.9 & 24.7 & 36.2 & 26.6 \\
\hline Pennisetum purpureum & 21.3 & 85.7 & n.d & 63.4 & 31.9 \\
\hline Trifolium baccarinii & 20,3 & 54,4 & 16,3 & 26,4 & 17,4 \\
\hline
\end{tabular}

*DM; dry mater, OM; Organic mater, CP; Crude proteins, NDF; Neutral Detergent Fiber, ADF; Acid Detergent Fiber, n.d*; not determined

\subsection{Palatibility of Forages}

Table 2 shows the Relative Index of Palatibility (RIP). 
Table 2. RIP of forages eaten by rabbits (Means \pm Sd)

\begin{tabular}{|c|c|c|c|c|c|}
\hline Forages & Botanical family & D. intortum & $\mathbf{n}^{*}$ & L. diversifolia & $\mathbf{n}^{*}$ \\
\hline Albizzia gummifera & Leguminoseae & $0.860 \pm 0.9 \mathrm{~d}$ & 6 & n.a & n.a \\
\hline Bidens pilosa & Asteracea & $1.0403 \pm 1 b c$ & 120 & $0.9961 \pm 1 \mathrm{ab}$ & 77 \\
\hline Brachiaria ruziziensis & Poaceae & $0.8197 \pm 0.8 \mathrm{de}$ & 30 & n.a & n.a \\
\hline Calliandra callothyrsus & Leguminoseae & $1.3938 \pm 1.4 \mathrm{a}$ & 8 & n.a & n.a \\
\hline Conyza sumatrensis & Asteracea & $0.8245 \pm 0.8 \mathrm{de}$ & 56 & $1.000 \pm 1 \mathrm{ab}$ & 77 \\
\hline $\begin{array}{l}\text { Crassocephalum } \\
\text { monteosum }\end{array}$ & Asteracea & $0.8844 \pm 09 \mathrm{~cd}$ & 9 & n.a & n.d \\
\hline $\begin{array}{l}\text { Crassocephalum } \\
\text { vitellinum }\end{array}$ & Asteracea & $0.9293 \pm 0.9 \mathrm{~cd}$ & 86 & $0.9366 \pm 0.9 b$ & 82 \\
\hline Desmodium intortum & Leguminoseae & $1.0260 \pm 1 b c$ & 72 & n.a & n.a \\
\hline $\begin{array}{l}\text { Dichrocephala } \\
\text { integrifolia }\end{array}$ & Asteracea & $1.0018 \pm 1 \mathrm{~cd}$ & 68 & $1.0000 \pm 1 \mathrm{ab}$ & 6 \\
\hline Digitaria vestita & Poaceae & $0.6317 \pm 0.6 \mathrm{e}$ & 6 & $0.8700 \pm 0.9 \mathrm{bc}$ & 10 \\
\hline Drimaria cordata & Caryopyllariaceae & n.a** & n.a & $0.8895 \pm 0.9 b c$ & 19 \\
\hline Erlangea sp & Asteracea & $0.9492 \pm 1 \mathrm{~cd}$ & 12 & $0.7750 \pm 0.8 \mathrm{c}$ & 12 \\
\hline Galinsoga parviflora & Asteracea & $1.0170 \pm 1 \mathrm{c}$ & 90 & $1.0895 \pm 1.1 \mathrm{a}$ & 38 \\
\hline Ipomoea batatas & Convulvulaceae & $1.0702 \pm 1.1 \mathrm{bc}$ & 107 & $1.0876 \pm 1.1 \mathrm{ab}$ & 89 \\
\hline Leucaena diversifolia & Leguminoseae & n.a & n.a & $0.9167 \pm 0.9 \mathrm{bc}$ & 48 \\
\hline Panicum repens & Poaceae & n.a & n.a & $0.9167 \pm 0.9 \mathrm{bc}$ & 6 \\
\hline Pennisetum purpureum & Poaceae & $0.7987 \pm 0.8 \mathrm{de}$ & 24 & $0.8500 \pm 0.9 b c$ & 6 \\
\hline Setaria barbata & Poaceae & $1.1640 \pm 1.2 b$ & 5 & n.a & n.a \\
\hline $\operatorname{Lsd}(p<0.05)$ & - & 0.14395 & - & 0.09634 & - \\
\hline
\end{tabular}

$\mathrm{n}^{*}=$ number of samples; $\mathrm{n} . \mathrm{a}^{* *}=$ data not available; Means with same letters within the same column do not differ significantly $(\mathrm{P}>0.05)$.

Tukey test grouping of RIP values shows five groups of means in the first trial and three in the second one. Only C. calothyrsus led to high palatability during the first trial; the trial with L. diversifolia supplement showed that the first group had only a moderate RIP. The frequencies of botanical families used in the trial of $D$. intortum suppplement were respectively $63.1 \%$ for Asteracea, and Convulvulacea $15.3 \%$, Leguminosea $12.3 \%$ and Poacea 9.3\%. The trial of $L$. diversifolia supplement mentionned Asteracea $62.2 \%$, Convulvulacea $18.9 \%$, Leguminosea $10.2 \%$, Poacea $4.7 \%$ and Caryophyllacea $4 \%$. The foliages botanical families have similar frequencies in the two trials even if in the second one there is one more family. 


\section{I Macrothink}

\subsection{Weight Gain}

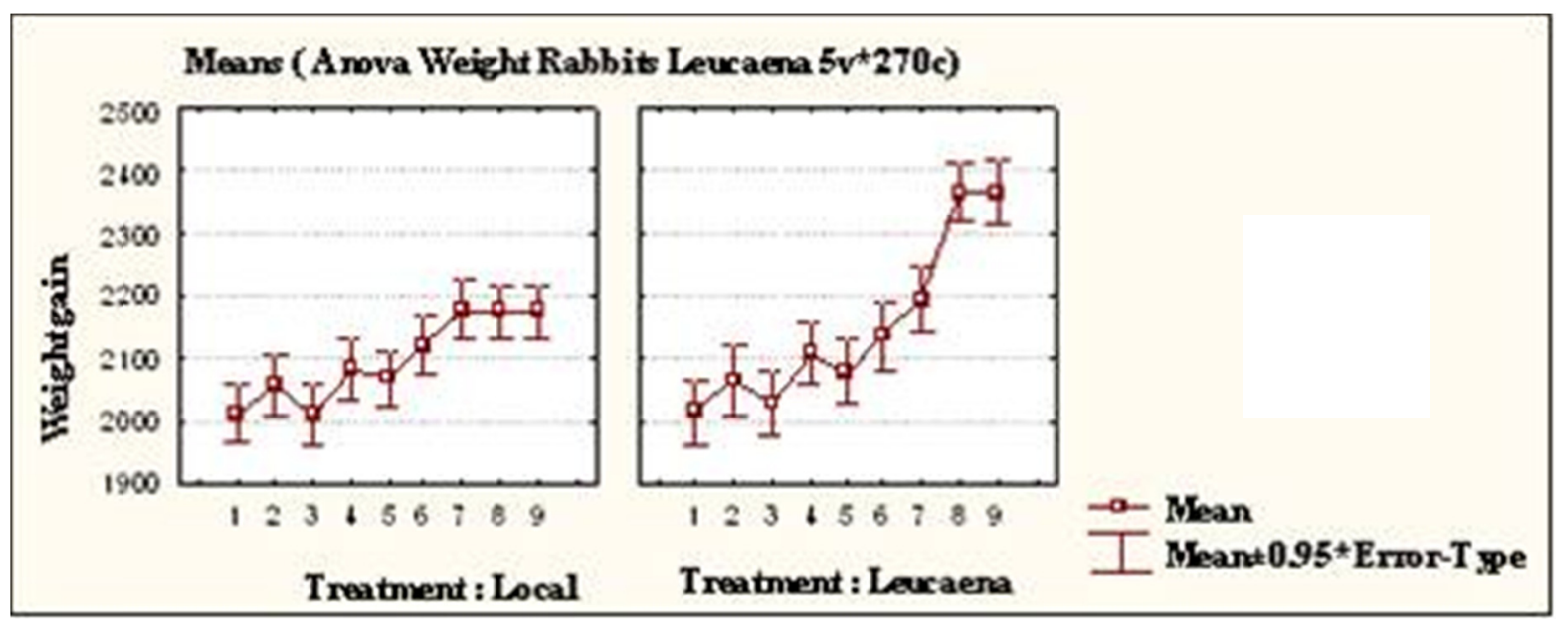

Figure 1. Weekly weight gain of rabbit fed with $L$. diversifolia supplement

The rabbits fed on the supplement of $L$. diversifolia showed a significant increase of live weight gain $(\mathrm{P}<0.05)$. Figure 3 shows that from the seventh week the weight of rabbits fed on the supplement of Leucaena divesrifolia increased significantly while the local control stagnated.

\section{Discussion}

\subsection{Palatibility of Forages}

During the two trials, only $C$. calothyrsus in the first trial led to a high RIP. Its low ADF concentration of $28.1 \%$ is an advantage because of its correlation with enzymatic digestibility (Heinritz et al., 2012) though its wide variation in condensed tannin concentrations (1.5-19.4\%) has also been reported (Cook et al., 2005). As foliages were harvested following the local farm practices with no emphasis on age, the palatability can vary within the foliage species. The improved forages $D$. intortum and $L$. diversifolia were recorded with moderate palatability but Desmodium intortum had been very well accepted by cavies (Bindelle et al., 2007). Palatability can be influenced by dry mater and the level of antinutritional factors such as tannins and hence the preference by animals (Osunga et al., 2008) as well as crude fiber content, post-ingestive factors and sensorial perception, previous experience with the feed (Solà-Oriol et al., 2009) and digestibility (Bindelle et al., 2007). Farmers did not necessary insist on the quality of the forages harvested because it was very difficult to select only young forages in sufficient quantities and determined species for the rabbits in the village. They usually also go far around 3 kilometers to collect forages. Leaves green Taiwan of the sweet potato has $19.4 \%$ of Crude proteins and possess a similar nourishing value to the one of the alfalfa (Dominguez, 2012). Leaves of I. batatas offered here were crop residues.

\subsection{Weight Gain}

The rabbits fed on L. diversifolia showed significant increases of live weight. 
gain. The curves of weight gain are not exponential especially in the supplement of $L$. diversifolia. We did not detect any symptom of intoxication during the trial with Leucaena, through many authors mentioned the mimosine toxin in this forage (Egli, 1988); (Kouonmenioc et al., 1991); (Heinritz et al., 2012). Otherwise (Scapinello et al., 2000) observed that L. leucocephala efficiently replaced alfalfa hay from $15 \%$ to $75 \%$ in diets for growing rabbits.

\section{Conclusion}

In term of palatability, the various forages supplied to female rabbits performed significantly less than C. calothyrsus with a high RIP in the first trial and the improved forages $D$. intortum and $L$. diversifolia had a moderate one during the second trial. Regarding, the weight gain of rabbits, the supplement $L$. diversifolia performed better than the local ones. The cropping of improved legumes constitutes an alternative to avoid long walks to collect fodder which is scarce in villages. These good forages on farm could remain available even in the dry season. Studies to determine the constraints of adoption of forage crops by farmers will help to improve forage production near the households and boost rabbit production.

\section{References}

Bindelle, J., Ilunga, Y., Delacollette, M., Muland, K. M., Umba, D. M'Balu. J., Kindele, E., \& Buldgen, A. (2007). Voluntary intake. chemical composition and in vitro digestibility of fresh forages fed to Cavies in periurban rearing systems of Kinshasa (Democratic Republic of Congo). Tropical Animal Health and Production, 39(6), 419-426. http://dx.doi.org/10.1007/s11250-007-9036-y

Cook, B., Pengelly, B., Brown, S., Donnelly, J., Eagles, D., Franco, A., ... Schultze-Kraft, R. (2005). CIAT, Tropical fodders Index fodders. Retrieved from www.tropicalfodders.info

Dominguez, P. L. (2012). Ipomoea batatas Patate douce Département de la Nutrition Institut de Recherche Porcine Gaveta Postal No1 Punta Brava. La Havane Cuba Référence utile: 612.

Egli, A. (1988). les arbres et arbustes fourragers au Rwanda Programme d'agroforesterie de l'ISAR 1982-1986 Butare Note technique n 2. ISAR Rwanda, p .67.

Heinritz, S. N., Hoedtke, S., Martens, S. D., Peters, M., \& Zeyner, A. (2012). Evaluation of ten tropical legume fodders for their potential as pig feed supplement .Livestock Research for Rural Development, 24(1).

International Center For Tropical Agriculture. (2008). More chicken and pork in the pot, and money in pocket: Improving forages for monogastric animals with low-income farmers Project foundended by Bundesministerium für Wirtschaftliche Zusammenarbeit und Entwicklung (BMZ) March 2008, p. 26.

Katunga, M. M. (2004). Le système agropastoral du Bushi et du Buhavu à l'est de la R. D. Congo face au défi de la malnutrition Edition CERPRU ISDR Bukavu RDC, p. 109.

Kouonmenioc, J., Lacoste, A., \& Et Guerin, H. (1991). Etude de l'influence de quatre fourrages ligneux sur l'évolution pondérale des ovins de la race naine de l'Afrique de l'Ouest Station de recherches zootechniques de Nkolbisson B. P. 1457. Yaoundé (Cameroun) 


\section{Macrothink}

Laboratoire de biologie végétale B Université de Paris XI Centre d'ORSAY (France) ${ }^{3}$ Institut d'élevage et de médecine vétérinaire des pays tropicaux (IEMVT) 10. rue Pierre Curie. Maisons-Alfort (France).

Maass, B. L., Katunga-Musale, D., Chiuri, W. L., \& Peters, M. (2012). 'Challenges and opportunities for smallholder livestock production in post-conflict South Kivu. eastern DR Congo'. Tropical Animal Health and Production. http://dx.doi.org/10.1007/s11250-011-0061-5

Osuga, I. M., Wambui, C. C., Abdulrazak, S. A., Ichinohe, T., \& Fujihara, T. (2008). Evaluation of nutritive value and palatability by goats and sheep of selected browse foliages from semiarid area of Kenya. Animal Science Journa, 79, 582-589. http://dx.doi.org/10.1111/j.1740-0929.2008.00567.x

Scapinello, C., Bianospino, E. A., Carlos, F. A., Cabrera, C. J., \& Garcia, D. F. H. (2000). Fenos de leucena (Leucaena leucocephala e Leucaena leucocephala cv. Cunningham) para coelhos em crescimento: digestibilidade e desempenho. Acta Scientiarum, 22(3), 829-833.

Solà-Oriol. D., Roura, E., \& Torrallardona, D. (2008). Feed preference: in pigs: Effect of cereal sources at different .J ANIM SCI, 87, 562-570. http://dx.doi.org/10.2527/jas.2008-0949

\section{Copyright Disclaimer}

Copyright reserved by the author(s).

This article is an open-access article distributed under the terms and conditions of the Creative Commons Attribution license (http://creativecommons.org/licenses/by/3.0/). 